Article

\title{
Annealing Behaviour of Pt and PtNi Nanowires for Proton Exchange Membrane Fuel Cells
}

\author{
Peter Mardle and Shangfeng Du * (ID \\ School of Chemical Engineering, University of Birmingham, Edgbaston, Birmingham B15 2TT, UK; \\ PJM556@student.bham.ac.uk \\ * Correspondence: s.du@bham.ac.uk; Tel.: +44-121-415-8696
}

Received: 20 July 2018; Accepted: 14 August 2018; Published: 19 August 2018

\begin{abstract}
PtNi alloy and hybrid structures have shown impressive catalytic activities toward the cathodic oxygen reduction reaction (ORR) in proton exchange membrane fuel cells (PEMFCs). However, such promise does not often translate into improved electrode performances in PEMFC devices. In this contribution, a Ni impregnation and subsequent annealing method, translatable to vertically aligned nanowire gas diffusion electrodes (GDEs), is shown in thin-film rotating disk electrode measurements (TFRDE) to enhance the ORR mass activity of Pt nanowires (NWs) supported on carbon (Pt NWs/C) by around 1.78 times. Physical characterisation results indicate that this improvement can be attributed to a combination of Ni alloying of the nanowires with retention of the morphology, while demonstrating that Ni can also help improve the thermal stability of Pt NWs. These catalysts are then tested in single PEMFCs. Lower power performances are achieved for PtNi $\mathrm{NWs} / \mathrm{C}$ than Pt NWs/C. A further investigation confirms the different surface behaviour between $\mathrm{Pt}$ NWs and PtNi NWs when in contact with electrolyte ionomer in the electrodes in PEMFC operation. Indications are that this interaction exacerbates reactant mass transport limitations not seen with TFRDE measurements.
\end{abstract}

Keywords: proton exchange membrane fuel cell (PEMFC); electrocatalyst; PtNi; nanowire; annealing

\section{Introduction}

In order for proton exchange membrane fuel cells (PEMFC) to become viable for full scale commercialisation, the catalyst activities and utilisation ratio of the precious metal catalysts, i.e., $\mathrm{Pt} / \mathrm{C}$ in catalyst electrodes needs to increase to improve the fuel cell power performance and reduce the system cost. To address this challenge, a lot of work has been conducted on the development of electrocatalysts toward the cathodic oxygen reduction reaction (ORR) for PEMFC applications over the past decades [1], and mass activities of above 30 times over the commercial $\mathrm{Pt} / \mathrm{C}$ catalyst have been reported [2-4]. However, due to the complex environment and unclear behaviour in operating electrodes, many novel electrocatalysts show poor performance in actual PEMFC operation despite much improved intrinsic catalytic activities demonstrated by the liquid half-cell measurement. A drive for PEMFCs at high current density operation [5,6] means that this end application needs to be more considered during the catalyst development.

One-dimensional (1D) Pt-based alloy and hybrid structures have been demonstrated showing remarkable catalytic activities for a variety of fuel cell reactions [7-9]. Concerning the ORR, alloying Pt with a non-precious metal such as $\mathrm{Ni}$ or $\mathrm{Co}$, etc. can provide inherent catalytic benefits resulting from lattice strain and electronic effects. They reduce the $\mathrm{Pt}-\mathrm{O}$ bond strength and thus shift the catalytic activity towards the theoretical maximum [10,11]. Additionally, Pt nanowires (NWs) have shown much higher specific activities toward the ORR in comparison to their OD counterparts, particularly because of 
the preferential exposure of crystal facets with single crystal nanowires [12,13]. Hence, a combination of the 1D morphology with alloy/hybrid structures has attracted much attention. Fundamental materials research has been conducted by Bu et al. who developed a variety of ultra-thin, long and crystalline PtM (M = Ni, Co, Fe, and Rh) NWs by a one-pot synthetic route, which demonstrated extraordinarily high catalytic activities for the ORR [3]. Utilising the Pt NW structure formed by the formic acid reduction method on carbon nanotubes, Elvington et al. deposited Ni onto the surface of Pt NWs by use of hydrazine monohydrate and sodium hydroxide [14]. The Ni was subsequently annealed into the $\mathrm{Pt}$ by means of thermal treatment in a reductive environment to provide a highly active catalyst for the ORR.

Alia et al. also produced ultra-long PtNi NWs by means of galvanic displacement of commercial Ni NWs with Pt [7]. The as-synthesised PtNi NWs showed 3-fold improvements in mass activity for the ORR over Pt NWs, aided by the retention of high electrochemically active surface areas (ECSA). Post treatment, such as thermal annealing [15] and acid treatment [16], have also been investigated to tailor these materials for practical use in PEMFCs. However, a large disparity is still observed between the intrinsic catalytic activity of the PtNi NWs and their performance in electrodes in fuel cells [17]. Therefore, to progress the development of high performance PEMFC devices from 1D Pt-based structures, their behaviour in practical electrodes need to be further understood on top of the improved inherent ORR catalytic activity.

Work previously conducted in our group has demonstrated that aligned Pt NWs can be grown directly on the carbon paper gas diffusion layer (GDL) by a simple and scalable formic acid reduction approach $[18,19]$. With the refinement of the growth temperature and by introducing nano-seeds on the GDL surface during the synthesis, Pt NW gas diffusion electrodes (GDEs) with better performances were achieved in comparison to conventional ones with the commercial Pt/C catalysts [19,20]. If analogous electrodes with similarly aligned PtNi NWs can be achieved, it can then potentially further enhance the fuel cell performance in applications.

In this work, a variety of PtNi NWs supported on carbon black (Vulcan XC-72R) are produced to understand the catalyst behaviour in fuel cell electrodes as a feasibility study. Pt NWs are grown on the carbon black particles using the formic acid approach at room temperature [21]. Ni is then deposited onto the surface of the Pt NWs using sodium borohydride in a simple wet chemical approach. Both PtNi and $\mathrm{Pt}$ NWs supported on carbon are then thermally annealed under a flow of $\mathrm{H}_{2}$. The effect of both annealing temperature and time on the morphology and structure of $\mathrm{Pt}$ and $\mathrm{PtNi} \mathrm{NWs}$ are discussed. The relation between the intrinsic activities of the 1D NWs determined by thin-film rotating disk electrode (TFRDE) measurement and their power performance in operating PEMFCs is also explored.

\section{Experimental}

\subsection{Materials}

$\mathrm{H}_{2} \mathrm{PtCl}_{6} \cdot 6 \mathrm{H}_{2} \mathrm{O}, \mathrm{HCOOH}(\geq 95 \%), \mathrm{NiCl}_{2} \cdot 6 \mathrm{H}_{2} \mathrm{O}$, and $\mathrm{NaBH}_{4}$ were purchased from Sigma-Aldrich (Gillingham, Dorset, UK). Vulcan XC-72R carbon black was purchased from the Fuel Cell Store (College Staion, TX, USA). Ethanol was purchased from Fisher Scientific (Loughborough, Leicestershire, UK). $10 \mathrm{M} \mathrm{NaOH}$ from Fluka Biochemika was used and diluted to $0.1 \mathrm{M}$ in-house. $10 \%$ Nafion ${ }^{\circledR}$ solution

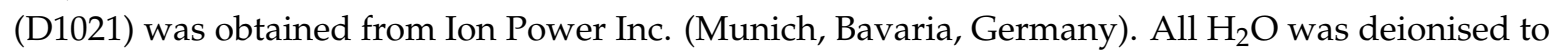
$18 \mathrm{M} \Omega \mathrm{cm}$ using a Millipore water system. For the liquid half cell measurement and fuel cell test, a benchmark commercial Pt/C catalyst (45.9 wt. \% Pt, TEC10E50E, Tanaka KikinzokuKogyo K. K. (TKK)) was used. 


\subsection{Preparation of $\mathrm{Pt} \mathrm{NWs} / \mathrm{C}$}

To prepare $60 \mathrm{wt}$. \% Pt NWs/C catalysts, $9.0 \mathrm{~mL}$ of $8 \mathrm{wt}$. \% $\mathrm{H}_{2} \mathrm{PtCl}_{6}$ aqueous solution was added to a dispersion of $240 \mathrm{mg}$ Vulcan XC-72R in $750 \mathrm{~mL} \mathrm{H}_{2} \mathrm{O} .48 \mathrm{~mL}$ of $\mathrm{HCOOH}$ was then added dropwise within $25 \mathrm{~min}$ under sonication. The reaction mixture was then left to react for $72 \mathrm{~h}$ before washing with $\mathrm{H}_{2} \mathrm{O}$ and then ethanol by centrifugation. The Pt NWs/C were then dried overnight in an oven at $60^{\circ} \mathrm{C}$.

\subsection{Preparation of PtNi NWs/C}

To impregnate Pt NWs/C with Ni, $300 \mathrm{mg}$ of the as-prepared Pt NWs/C was dispersed in a solution of $73 \mathrm{mg} \mathrm{NiCl} 2 \cdot 6 \mathrm{H}_{2} \mathrm{O}$ in $180 \mathrm{~mL} 0.1 \mathrm{M} \mathrm{NaOH}$ to achieve a theoretical Pt:Ni atomic ratio 3:1. $80 \mathrm{mg}$ of $\mathrm{NaBH}_{4}$ was then dissolved in $40 \mathrm{~mL}$ of $0.1 \mathrm{M} \mathrm{NaOH}$ before adding dropwise to the $\mathrm{Pt} \mathrm{NW} / \mathrm{C}$ and $\mathrm{NiCl}_{2}$ dispersion under vigorous stirring. After $1 \mathrm{~h}$, the PtNi NWs/C were washed and dried as above with the Pt NWs/C samples.

\subsection{Annealing of Pt NWs/C and PtNi NWs/C}

$\mathrm{Pt}$ NWs $/ \mathrm{C}$ and PtNi NWs /C were thermally annealed at 150,250 , and $350{ }^{\circ} \mathrm{C}$ for $24 \mathrm{~h}$ under a $50 \mathrm{~mL} \mathrm{~min}^{-1}$ flow of $4 \% \mathrm{H}_{2} / \mathrm{Ar}$ in a tube furnace (Vecstar Ltd. Chesterfield, Derbyshire, UK) with a heating and cooling rate of $2{ }^{\circ} \mathrm{C} \mathrm{min}^{-1}$. A PtNi NWs $/ \mathrm{C}$ sample was also annealed at $150{ }^{\circ} \mathrm{C}$ for $72 \mathrm{~h}$ to study the influence of annealing duration. The annealing temperature used is stated in brackets throughout the report.

\subsection{Physical Characterisation}

Transmission electron microscopy (TEM) and energy dispersive X-ray spectroscopy (EDX) analyses of the Pt NWs/C and PtNi NWs/C before and after annealing were conducted with a Jeol2100 FEG-TEM (JEOL Ltd. Welwyn Garden City, Hertfordshire, UK) at an accelerating voltage of $200 \mathrm{kV}$ to assess the morphology and chemical composition of the NANOWIREs. In order to assess the crystallinity and Ni alloying degree in the PtNi NWs/C samples, powder X-ray diffraction (XRD) was recorded using a Bruker D8 Auto-sampler (Bruker Corp. Billerica, MA, USA), utilising a Cu K $\alpha$ $X$-Ray source $(\lambda=0.15406 \mathrm{~nm})$. The XRD was ran between $2 \theta$ values of $20-90^{\circ}$ with a step size of $0.02^{\circ}$ and dwell time of $0.47 \mathrm{~s}$. X-ray photoelectron spectroscopy (XPS) was conducted with an XPS spectrometer (K-Alpha, Thermo Scientific, Loughborough, Leicestershire, UK) using a micro-fused monochromatic $\mathrm{Al} \mathrm{K} \alpha$ source $(1486.6 \mathrm{eV})$. Thermo-gravimetric analysis (TGA) was conducted with a NETZSCH TG209F1 (NETZSCH GmbH. Selb, Bavaria, Germany) in the temperature range $20-700{ }^{\circ} \mathrm{C}$ at a heating rate of $10^{\circ} \mathrm{C} \mathrm{m^{-1 }}$ under a $40 \mathrm{~mL} \mathrm{~min}^{-1}$ air flow.

\subsection{Thin-Film Rotating Disk Electrode Measurement (TFRDE)}

TFRDE measurements were performed to evaluate the catalyst activities using a standard 3 electrode rotating disk electrode (RDE) setup with an Autolab PGSTAT302N potentiostat (Metrohm Ltd. Runcorn, Cheshire, UK). $5 \mathrm{mg}_{\text {Catalyst }} \mathrm{mL}^{-1}$ catalyst ink with volume ratios $\mathrm{H}_{2} \mathrm{O}$ :IPA:Nafion ${ }^{\circledR}$ 0.79:0.2:0.01 was homogenised using both ultra-sonic cleaner and horn. A Sonics Vibra-CellTM VCX130 sonication horn was used at $20 \%$ power for $10 \mathrm{~min}$ sonic time in a $10 \mathrm{~s}$ on/10 s off pulse sequence. Five $\mu \mathrm{L}$ of the fresh ink was pipetted onto a $0.196 \mathrm{~cm}^{2}$ Pine Instruments (Pine Research Instrumentation Inc. Durham, County Durham, UK) glassy carbon electrode (GCE) which was pre-polished using alumina slurries. The electrode was then left for drying under a rotation speed of $600 \mathrm{rpm}$ in ambient conditions thus ensuring a homogeneous thin film paramount for an accurate comparison of catalyst samples [22,23]. An in-house prepared reference hydrogen electrode (RHE) and Pt gauze were used as the reference and counter electrodes respectively. $0.1 \mathrm{M} \mathrm{HClO}_{4(\mathrm{aq})}$ was used as the electrolyte and was maintained at $25^{\circ} \mathrm{C}$ by a water bath. After the electrolyte was saturated with $\mathrm{N}_{2}, 50$ cyclic voltammograms (CVs) were run in the potential range $0.05-1.2 \mathrm{~V}$ at a scan rate of $100 \mathrm{mV} \mathrm{s}^{-1}$ to electrochemically clean the surface followed by 3 scans at $20 \mathrm{mV} \mathrm{s}^{-1}$ (staircase, $0.00244 \mathrm{~V}$ ). 
The hydrogen desorption region $\left(\mathrm{H}_{\mathrm{des}}\right)$ of the final scan was used to calculate the electrochemical effective surface area (ECSA) although it is noted that use of a staircase scan could underestimate the true value due to the fast hydrogen adsorption/desorption process [24]. Kinetic currents were then obtained by means of a Koutecky-Levich analysis from background and internal resistance corrected linear sweep voltammograms $\left(0.05-1.2 \mathrm{~V}\right.$ vs. $\left.\mathrm{RHE}, 20 \mathrm{mV} \mathrm{s}^{-1}\right)$ in $\mathrm{O}_{2}$ saturated electrolyte at rotation rates of 400, 800,1200, 1600, and $2000 \mathrm{rpm}$. Specific and mass activities were calculated by normalising the kinetic current with respect to electrochemically active Pt surface area and Pt mass, respectively. The mass was calculated assuming $60 \mathrm{wt}$ \% for Pt NWs/C samples and $56.6 \mathrm{wt}$. \% for PtNi NWs/C samples. The internal resistances were determined from electrochemical impedance spectroscopy (EIS) at the intersection point with the real axis.

\subsection{Membrane Electrode Assemble (MEA) Preparation and Test}

Typically, catalyst electrodes were made by firstly preparing a catalyst ink of $14 \mathrm{mg}$ of catalyst $\left(0.4 \mathrm{mg}_{\mathrm{Pt}} \mathrm{cm}^{-2}\right.$ in final electrodes, ca. $24 \%$ lost in painting) in $0.5 \mathrm{~mL}$ IPA and $90.5 \mu \mathrm{L} \mathrm{Nafion}{ }^{\circledR}$ solution, by use of sonication. The ink was painted onto a $4 \times 4 \mathrm{~cm}^{2}$ piece of Sigracet 35BC GDL and dried in air. Membrane electrode assemble were then fabricated by hot pressing the as-prepared electrodes with a $6 \times 6 \mathrm{~cm}^{2}$ Nafion 212 membrane and a commercial Johnson Matthey anode $\left(0.4 \mathrm{mg}_{\mathrm{Pt}} \mathrm{cm}^{-2}\right)$ on which a thin layer of Nafion ${ }^{\circledR}$ ionomer had been coated in advance. Hot pressing was carried out at a pressure of $4.9 \mathrm{MPa}$ at $135^{\circ} \mathrm{C}$ for $2 \mathrm{~min}$.

The fabricated MEAs were tested at $80^{\circ} \mathrm{C}$ in a PaxiTech-BioLogic FCT-50S PEMFC test stand (PaxiTech SAS. Grenoble, Auvergne-Rhône-Alpes, France). Polytetrafluoroethylene (PTFE) gaskets with a thickness of $254 \mu \mathrm{m}$ were used at both the anode and cathode. The break-in procedure and polarisation curve acquisition followed the harmonised EU protocol [25]. For the polarisation curves and EIS, the air $/ \mathrm{H}_{2}$ relative humidity $(\mathrm{RH})$, stoichiometric coefficient and absolute pressure was $30 \% / 50 \%, 1.5 / 1.3$, and 2.3/2.5 bar, respectively. Galvano EIS was conducted at 0.48 A with amplitude $72 \mathrm{~mA}$ in the frequency range $10-0.1 \mathrm{~Hz}$. Potentio EIS was conducted at $0.65 \mathrm{~V}$ and $0.5 \mathrm{~V}$ with amplitude $10 \mathrm{mV}$ in the same frequency range as with the galvano EIS measurement.

\section{Results and Discussion}

\subsection{Physical Characterisation}

Figure 1 shows TEM images of Pt NWs/C and PtNi NWs/C samples before and after annealing at various temperatures. Figure 1a shows that while a lot of singular Pt NWs grow on the carbon surface, the majority of the nanowires are formed into large agglomerates with an average size of ca. $120 \mathrm{~nm}$. Based on the similarities of these agglomerates with previous investigations of Pt NWs grown using formic acid, it seems that the size and shape of the Pt NW agglomerates depends primarily on the underlying seed formed on the support [21,26], and the nanowire growth rate [27]. Control of the growth temperature [19], the separate introduction of seed particles [26], and a variety of other factors such as precursor selection [28] can give better control over this agglomeration. However, the optimisation procedure of the growing process in large quantities is beyond the research topic in this work, considering the principle investigation here is the annealing behaviour. Of more importance is the fact that all samples are derived from the exact same initial batch of $\mathrm{Pt} \mathrm{NWs} / \mathrm{C}$, thereby all differences found from the TFRDE and MEA tests are solely due to the inclusion of $\mathrm{Ni}$ and annealing temperature used, and not differences in initial Pt NW structure and distribution. 

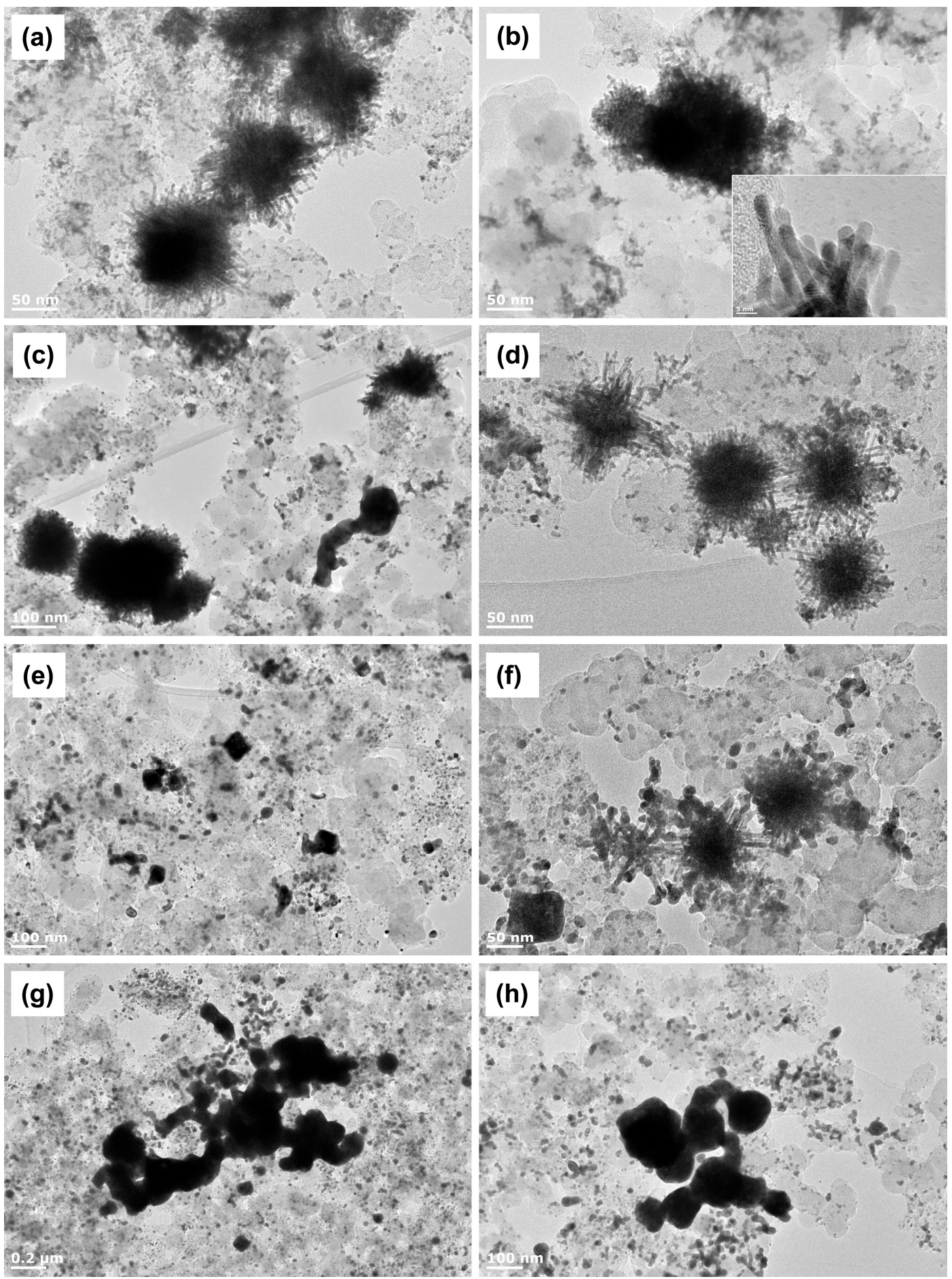

Figure 1. TEM images of (a) Pt nanowires (NWs)/C; (b) PtNi NWs/C; (c) Pt NWs $/ \mathrm{C}\left(150^{\circ} \mathrm{C}\right)$; (d) PtNi NWs /C (150 $\left.{ }^{\circ} \mathrm{C}\right) ;(\mathbf{e}) \mathrm{Pt}$ NWs $/ \mathrm{C}\left(250^{\circ} \mathrm{C}\right) ;(\mathbf{f}) \mathrm{PtNi}$ NWs $/ \mathrm{C}\left(250^{\circ} \mathrm{C}\right) ;(\mathrm{g}) \mathrm{Pt} \mathrm{NWs} / \mathrm{C}\left(350^{\circ} \mathrm{C}\right)$; and (h) $\mathrm{PtNi}$ NWs $/ \mathrm{C}\left(350^{\circ} \mathrm{C}\right)$. Inset $1 \mathrm{~b}$ show the HR-TEM images of the PtNi NWs.

The individual Pt NWs (Figure 1a) as part of the agglomerates have an average diameter of $3.40 \mathrm{~nm}$. Based on a measured inter-lattice spacing of $0.22 \mathrm{~nm}$, evidence suggests NW growth in the $<111>$ direction, leading to the preferential exposure of highly active crystal facets. Upon the impregnation of $\mathrm{Ni}$, the wire diameter increased to $3.59 \mathrm{~nm}$ and the inter-lattice spacing remained at $0.22 \mathrm{~nm}$. EDX element mapping were also run and the results for one PtNi NWs/C sample is shown in 
Figure S1 where the distribution of Ni throughout the agglomerate is clear however resolution was not sufficient to show the distribution of $\mathrm{Ni}$ on an individual nanowire.

The TEM images of the Pt NWs/C and PtNi NWs/C samples under various annealing temperatures are also shown in Figure 1. Under a mild annealing temperature of $150{ }^{\circ} \mathrm{C}$, the nanowire diameters of the Pt NWs/C and PtNi NWs/C are found to be $5.06 \mathrm{~nm}$ and $3.56 \mathrm{~nm}$, respectively. Shown in Figure $1 \mathrm{c}$ is also an instance where sintering of $\mathrm{Pt} \mathrm{NWs} / \mathrm{C}$ had occurred. Figure $1 \mathrm{~d}$ indicates that at this annealing temperature, the morphology of $\mathrm{PtNi} N W s / C$ can be completely retained, thus evidencing the presence of $\mathrm{Ni}$ on the Pt nanowires. At a higher annealing temperature of $250{ }^{\circ} \mathrm{C}$, the vast majority of Pt NWs and PtNi NWs have sintered, and an average diameter of $8.58 \mathrm{~nm}$ are found for the PtNi NWs $/ \mathrm{C}$. At $350^{\circ} \mathrm{C}$, severe coarsening happens and the large nanowire agglomerates sinter into large particles. This result demonstrates both the mobility of the Pt on the carbon surface at temperature [29] and critically that the ultra-high annealing temperatures of up to $900{ }^{\circ} \mathrm{C}$ that can be used for supported nanoparticles [30,31] cannot be used if the ultra-thin nanowire morphology needs to be retained. To further understand the influence of annealing duration, annealing was conducted for PtNi NWs/C for $72 \mathrm{~h}$. The average nanowire diameter after annealing is ca. $3.53 \mathrm{~nm}$ (Figure S2) indicating that a longer annealing time does not result in severe sintering.

XRD analysis was conducted to the PtNi NWs/C samples in order to compare the degree of PtNi alloying at each annealing temperature (Figure 2). The XRD patterns of Pt NWs/C, PtNi NWs/C, and PtNi NWs $/ \mathrm{C}\left(150^{\circ} \mathrm{C}\right)$ all have similar peak positions to the pure crystalline $\mathrm{Pt}$ with calculated lattice spacings of $3.913,3.914$, and $3.917 \AA$ respectively. It is only at the higher annealing temperatures of 250 and $350{ }^{\circ} \mathrm{C}$, with respective lattice constants of 3.908 and $3.906 \AA$ that a notable shift in lattice constant is observed. However, this shift is much smaller in comparison to other PtNi studies [32,33] demonstrating that the alloying here only occurs below the Pt surface, not affecting the bulk nanowire composition [14]. No characteristic Ni peaks are found in the XRD patterns, indicating that the Ni successfully incorporates into the Pt lattice structure in the PtNi NWs/C samples. From the XRD patterns an increase in peak intensity is also observed corresponding to an increase in particle size, consistent with TEM analysis results above [33].

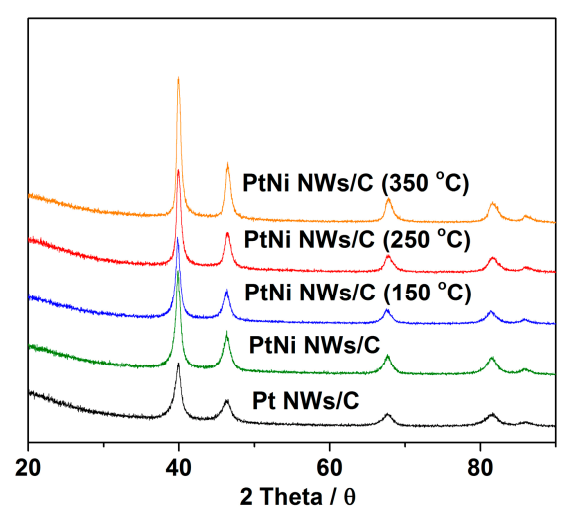

Figure 2. XRD patterns of $\mathrm{Pt} \mathrm{NWs} / \mathrm{C}$ and $\mathrm{PtNi} \mathrm{NWs} / \mathrm{C}$.

XPS analysis of the Pt NWs/C and Pt NWs/C samples was also performed to ascertain the nature of the $\mathrm{Pt}$ and $\mathrm{Ni}$ in each sample (Figure 3 and Figure S3). For all samples, the best fit for $\mathrm{Pt} 4 \mathrm{f}$ peaks is found with the inclusion of both $\mathrm{PtO}$ and $\mathrm{PtO}_{2}$ (Table S1). For the high resolution Ni regions, $\mathrm{Ni}(\mathrm{OH})_{2}$ is found to be the largest contributor to the non-satellite peaks. However, the $\mathrm{Ni}(\mathrm{OH})_{2}$ content decreases and the Ni content increases with the annealing temperature (Table S2). This supports the XRD analysis results with the conclusion that higher degrees of alloying are obtained at the higher annealing temperatures, where $\mathrm{Pt}$ surface segregation is more prominent and reduction of the $\mathrm{Ni}$ hydroxides by the $\mathrm{H}_{2}$ gas leads to sub-surface $\mathrm{Ni}$ [34]. The sintering of the nanowires is also a cause in positioning the Ni within the large crystalline agglomerates of Figure $1 \mathrm{~h}$. 

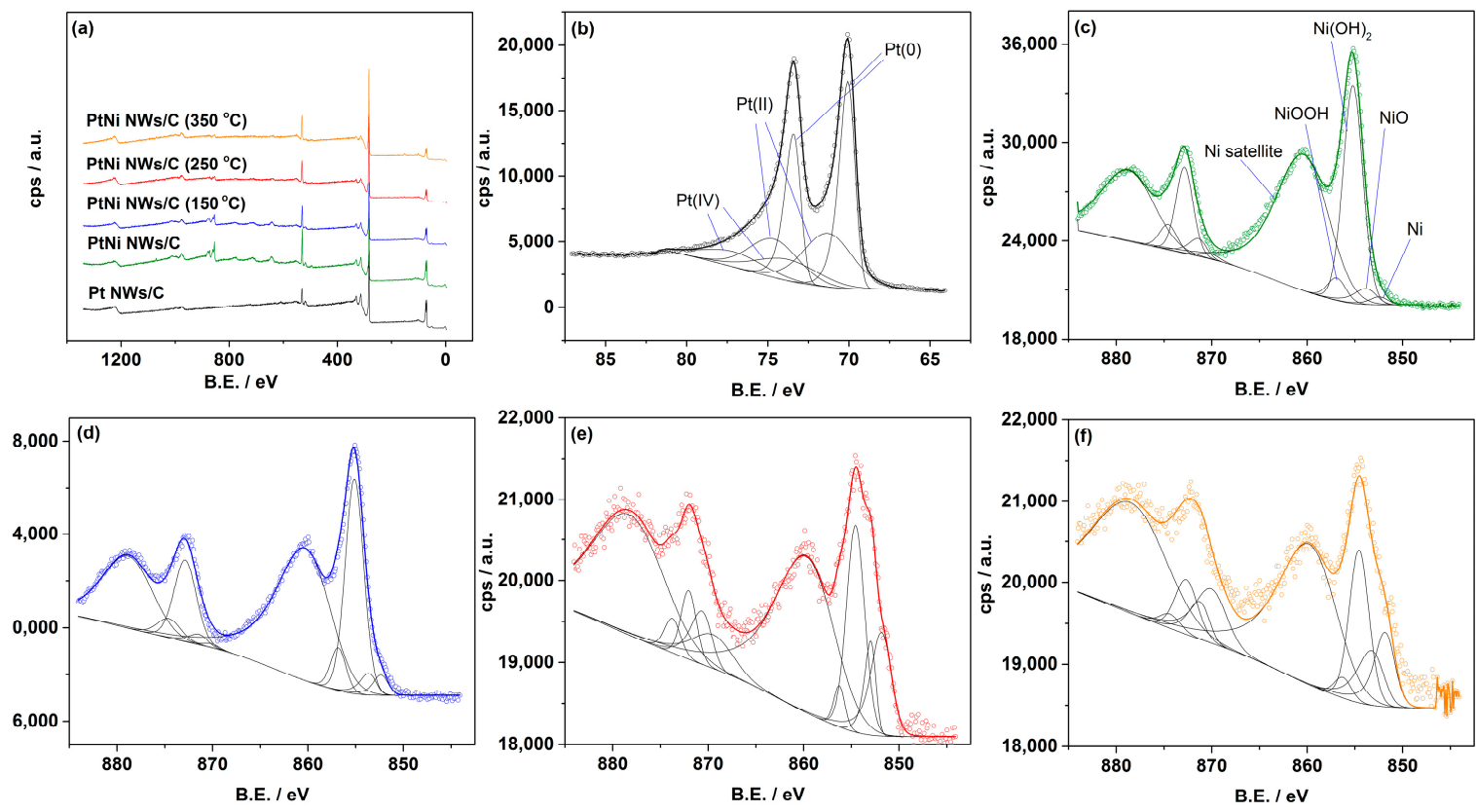

Figure 3. (a) XPS Survey scan of Pt NWs/C, PtNi NWs/C, and PtNi NWs/C annealed at various temperatures. XPS patterns of (b) Pt $4 \mathrm{f}$ scan for Pt NWs/C; (c) Ni 3p scan for PtNi NWs/C; (d) Ni 3p scan for PtNi NWs $/ \mathrm{C}\left(150^{\circ} \mathrm{C}\right)$; (e) Ni $3 \mathrm{p}$ scan for PtNi NWs $/ \mathrm{C}\left(250^{\circ} \mathrm{C}\right)$; and $(\mathbf{f}) \mathrm{Ni} \mathrm{3p}$ scan for PtNi NWs $/ \mathrm{C}\left(350^{\circ} \mathrm{C}\right)$.

Evidence of a larger proportion of surface Ni hydroxides is also found for the PtNi NWs/C and $\mathrm{PtNi} N W s / \mathrm{C}\left(150^{\circ} \mathrm{C}\right)$ using thermogravimetric analysis (TGA). A drop in residual mass at around $200-300{ }^{\circ} \mathrm{C}$ in the TGA (Figure S4) is ascribed to the decomposition of surface hydroxide species [35]. However, no such drop is observable for the samples annealed at $250{ }^{\circ} \mathrm{C}$ and $350{ }^{\circ} \mathrm{C}$, coinciding with the much reduced hydroxide content found in the XPS analysis. The residual mass of $61 \% \mathrm{for} \mathrm{Pt}$ NWs $/ \mathrm{C}$ and $55 \%$ for PtNi NWs/C annealed at $350{ }^{\circ} \mathrm{C}$ are very close to the assumed Pt loadings of 60 wt. \% for the Pt NWs/C samples and 56.6 wt. \% for the PtNi NWs/C samples, respectively.

\subsection{Ex-Situ ORR Catalytic Activities}

TFRDE tests have been extensively used to evaluate the inherent catalytic activity of a material towards ORR [36], and in this work they were used to evaluate the effect of the annealing temperature on the ECSA and catalytic performance of Ni impregnated Pt NW catalysts. A full Koutecky-Levich analysis (Figure S5) was used in this work over the conventionally used mass transport correction due to the fact that the current at $0.9 \mathrm{~V}$ vs. RHE was not always less than $i_{d} / 2$, where $i_{d}$ is the diffusion limited current [22,37].

Figure 4a shows a comparison of the obtained ECSAs and specific activities for the commercial $\mathrm{Pt} / \mathrm{C}$ (TKK) catalyst and the $\mathrm{Pt} \mathrm{NWs} / \mathrm{C}$ before and after Ni impregnation. For the commercial catalyst an ECSA and specific activity of $85.7 \mathrm{~m}^{2} \mathrm{gPt}^{-1}$ and $292 \mu \mathrm{A} \mathrm{cm}_{\mathrm{Pt}}{ }^{-2}$ are obtained meeting the expected standard [22]. However for the $\mathrm{Pt} \mathrm{NWs} / \mathrm{C}$ the heavy agglomeration results in a small ECSA of $13.1 \mathrm{~m}^{2} \mathrm{gPt}^{-1}$, and the surface $\mathrm{Ni}$ impregnation reduces this to $8.0 \mathrm{~m}^{2} \mathrm{gPt}^{-1}$. The TGA and XPS analysis has shown a high level of Ni hydroxides suggesting that without the annealing process, the $\mathrm{Ni}$ resides on the surface of the Pt nanowires, partially blocking otherwise catalytically active sites on the surface. For the Pt NWs/C and PtNi NWs/C catalysts, specific activities of $536 \mu \mathrm{A} \mathrm{cm}_{\mathrm{Pt}^{-}}{ }^{-2}$ and $769 \mu \mathrm{A} \mathrm{cm}_{\mathrm{Pt}}{ }^{-2}$ are obtained respectively. Based on previous studies, such increases in the specific activity can be attributed to the inherent benefits of 1D morphology while the Ni contributes to a further boost in activity through electronic and structural effects [10,38]. 

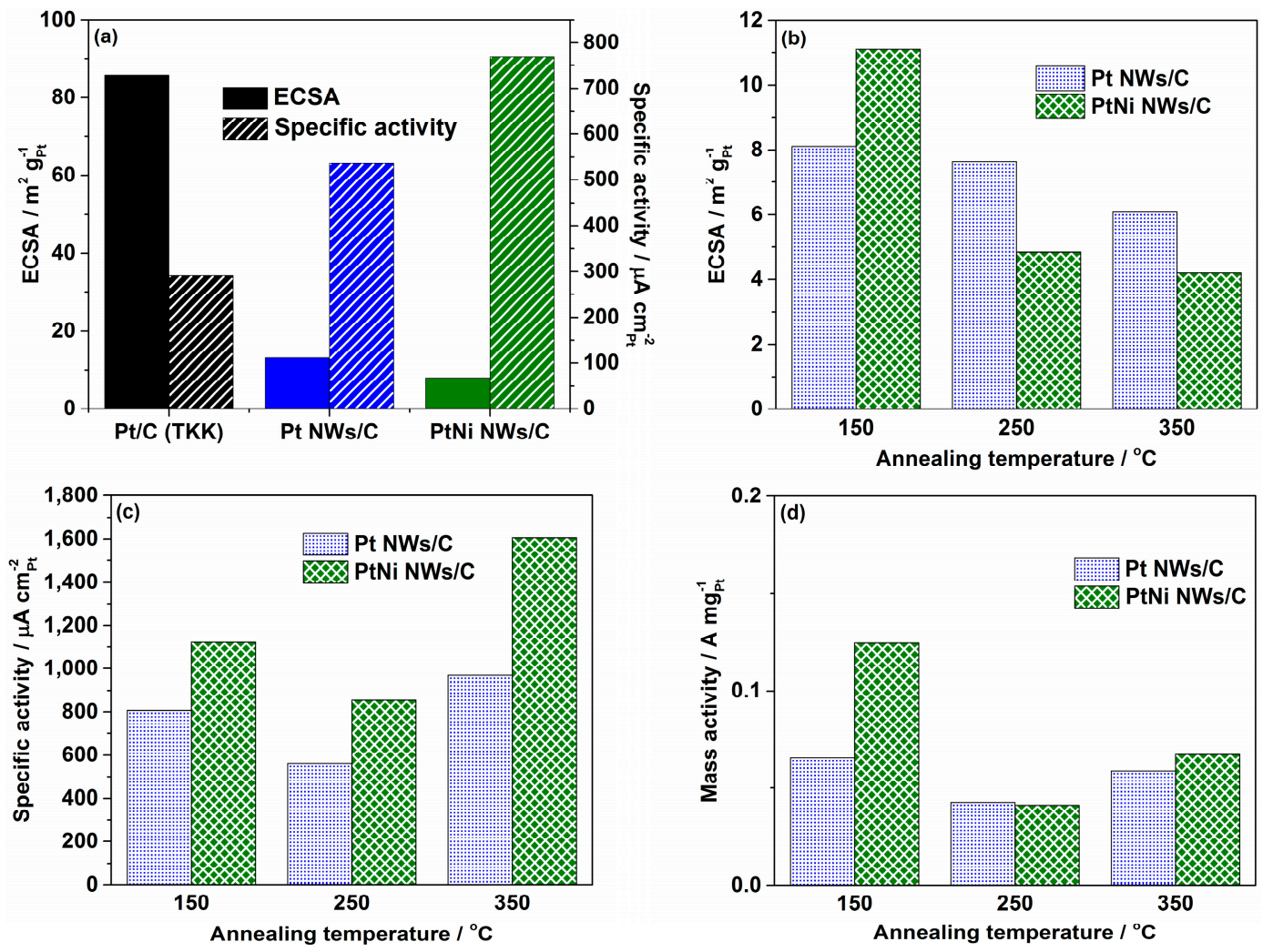

Figure 4. (a) Electrochemically active surface areas (ECSA), specific, and mass activity of Pt/C (TKK), $\mathrm{Pt}$ NWs/C, and PtNi NWs/C; (b) ECSA; (c) Specific activity and (d) Mass activity of annealed samples of $\mathrm{Pt} \mathrm{NWs} / \mathrm{C}$, and $\mathrm{PtNi} \mathrm{NWs} / \mathrm{C}$ determined from the thin-film rotating disk electrode measurements (TFRDE) measurement.

Of interest is the effect that the annealing temperature has on the catalytic performance of the nanowire catalysts. As a result of the sintering present at a temperature as low as $150{ }^{\circ} \mathrm{C}$, the ECSAs of the Pt NWs/C samples drop from $13.1 \mathrm{~m}^{2} \mathrm{~g}_{\mathrm{Pt}}{ }^{-1}$ before annealing to 8.1, 7.6, and $6.1 \mathrm{~m}^{2} \mathrm{~g}_{\mathrm{Pt}}{ }^{-1}$ after annealing at 150,250 , and $350{ }^{\circ} \mathrm{C}$ respectively. However, while PtNi NWs/C had an ECSA of $8.0 \mathrm{~m}^{2} \mathrm{~g}_{\mathrm{Pt}}{ }^{-1}$, after annealing at $150{ }^{\circ} \mathrm{C}$, the ECSA increases to $11.1 \mathrm{~m}^{2} \mathrm{gPt}^{-1}$. It appears that on annealing, some of the impregnated Ni segregates below the Pt surface, unblocking some Pt active sites while retaining nanowire morphology. However, despite improved resistance to agglomeration in comparison to Pt NWs/C as suggested by the TEM analysis, the ECSA of the PtNi NWs/C annealed at 250 and $350{ }^{\circ} \mathrm{C}$ decrease to be 4.8 and $4.2 \mathrm{~m}^{2} \mathrm{~g}_{\mathrm{Pt}}{ }^{-1}$ respectively. A contributing factor can be an underestimation of the ECSA due to modified electronic properties of the Pt surface [39]. An ECSA of $9.3 \mathrm{~m}^{2} \mathrm{gPt}^{-1}$ is obtained for PtNi NWs/C annealed at $150^{\circ} \mathrm{C}$ for $72 \mathrm{~h}$., supporting the observation that while the nanowire morphology is stable at $150{ }^{\circ} \mathrm{C}$ for extended periods of time (Figure S2), the degree of nanowire agglomeration still increases.

Upon annealing at $150{ }^{\circ} \mathrm{C}$, the specific activity of $\mathrm{Pt} \mathrm{NWs} / \mathrm{C}$ and $\mathrm{PtNi} \mathrm{NWs} / \mathrm{C}$ increase to respective values of 808 and $1123 \mu \mathrm{A} \mathrm{cm}_{\mathrm{Pt}}{ }^{-2}$ (Figure 4c). For the Pt NWs/C the sintering of defect sites is attributable to this increase in observable activity. Resulting from the loss of preferential exposure of highly active facets, after annealing at $250{ }^{\circ} \mathrm{C}$ the specific activity for $\mathrm{Pt} \mathrm{NWs} / \mathrm{C}$ is found to be $561 \mu \mathrm{A} \mathrm{cm}_{\mathrm{Pt}}{ }^{-2}$, less than the untreated Pt NWs/C. An increase in specific activity to $968 \mu \mathrm{A} \mathrm{cm} \mathrm{Pt}^{-2}$ at the highest studied annealing temperature of $350{ }^{\circ} \mathrm{C}$ however can be attributed to the increase in particle size and a reduced proportion of defect sites to crystal faces [40].

A similar relation of annealing temperature to specific activity is observed for the $\mathrm{PtNi} N W s / C$ samples where specific activities of 1123,855 , and $1606 \mu \mathrm{A} \mathrm{cm}_{\mathrm{Pt}}{ }^{-2}$ are observed after annealing at 
150,250 , and $350^{\circ} \mathrm{C}$ respectively. Longer annealing times at $150{ }^{\circ} \mathrm{C}$ negatively affected the activity of the PtNi NWs/C where a specific activity of $889 \mu \mathrm{Acm}_{\mathrm{Pt}}{ }^{-2}$ is obtained. With higher activities in comparison to the $\mathrm{Pt} \mathrm{NWs} / \mathrm{C}$ analogues, these tests have shown that the impregnation with annealing process can be used to increase the inherent specific catalytic activities of $\mathrm{Pt} \mathrm{NW}$ catalysts toward the ORR. Of particular importance for practical applications is however the mass activity. Although the mass activity of all prepared samples falls short of the commercial $\mathrm{Pt} / \mathrm{C}$ (TKK) catalyst, this is a direct consequence of the lower ECSAs and absolute surface area of $\mathrm{Pt}$, itself resulting from the aforementioned commitment to use of the same $\mathrm{PtNW} / \mathrm{C}$ batch for accurate interpretation of the effect of thermal annealing.

At higher annealing temperatures, the mass activity of the synthesised catalysts is not much improved for the presence of $\mathrm{Ni}$ due to the lower ECSAs. However, the retention of nanowire morphology for PtNi NWs $/ \mathrm{C}\left(150^{\circ} \mathrm{C}\right)$, and an impressive specific activity deriving from a combination of the Ni alloying and the removal of defect sites results in a 1.78-fold mass activity improvement over the initial Pt NWs/C catalysts. Therefore, PtNi NWs/C annealed for $24 \mathrm{~h}$ at $150{ }^{\circ} \mathrm{C}$ is selected as a candidate material for the fabrication of the high performance PtNi NW electrodes $[19,41]$.

\subsection{MEA Testing}

In order to better understand the annealing effect, and to discern whether the activity enhancements demonstrated in the TFRDE measurements can be translated into higher electrode power outputs, the as-prepared catalysts were made into $16 \mathrm{~cm}^{2}$ GDEs and tested in single PEMFCs (Figure 5). In single cells, the open circuit potential (OCP) of all samples are comparable to each other and notably the activity of the catalysts at $0.9 \mathrm{~V}$ are not enhanced too much by the inclusion of $\mathrm{Ni}$ in the samples. One of the main challenges for PEMFC development is in realising the promising catalytic activities of novel PtNi catalysts in a working PEMFC. For this purpose, a much deeper understanding of the characteristics of PtNi alloys in MEAs is imperative.

Of more concern than the similar power performance at high potential for $\mathrm{Pt}$ and $\mathrm{PtNi} \mathrm{NWs} / \mathrm{C}$ is the drop in performance at higher current densities for the PtNi NWs/C samples. At higher current densities, mass transport limitations become prominent, leading to a sudden drop in cell potential and power output. From the Pt NWs/C samples it appears that the severe coarsening of the nanowires does not change the electrode performance as much as might be predicted. Considering the agglomeration of the nanowires, the Nafion ${ }^{\circledR}$ ionomer in catalyst electrodes is unable to access the entire surface of each nanowire [42]. This implies that in a MEA, each nanowire agglomerate would show similar mass transport characteristics as a single large particle hence giving similar electrode power performances before and after the annealing process. Such results reiterate the importance of dispersion of $1 \mathrm{D}$ structures to maximise the triple-phase boundary and to reduce mass transport resistances in electrodes.

To illustrate this further, the sample of PtNi NWs $/ \mathrm{C}$ annealed at $150{ }^{\circ} \mathrm{C}$ for $72 \mathrm{~h}$ shows a higher mass transport resistance compared to the $\mathrm{PtNi} N W s / \mathrm{C}$ annealed for $24 \mathrm{~h}$ despite a similar charge transfer resistance (Figure $5 \mathrm{c}, \mathrm{e}$ ). This result can be attributed to the increased aggregation despite similar nanowire diameters found for this sample. Therefore while nanowire morphology is important for improving mass transport limitations in PEMFCs, of greater importance is the distribution of those nanowires. 

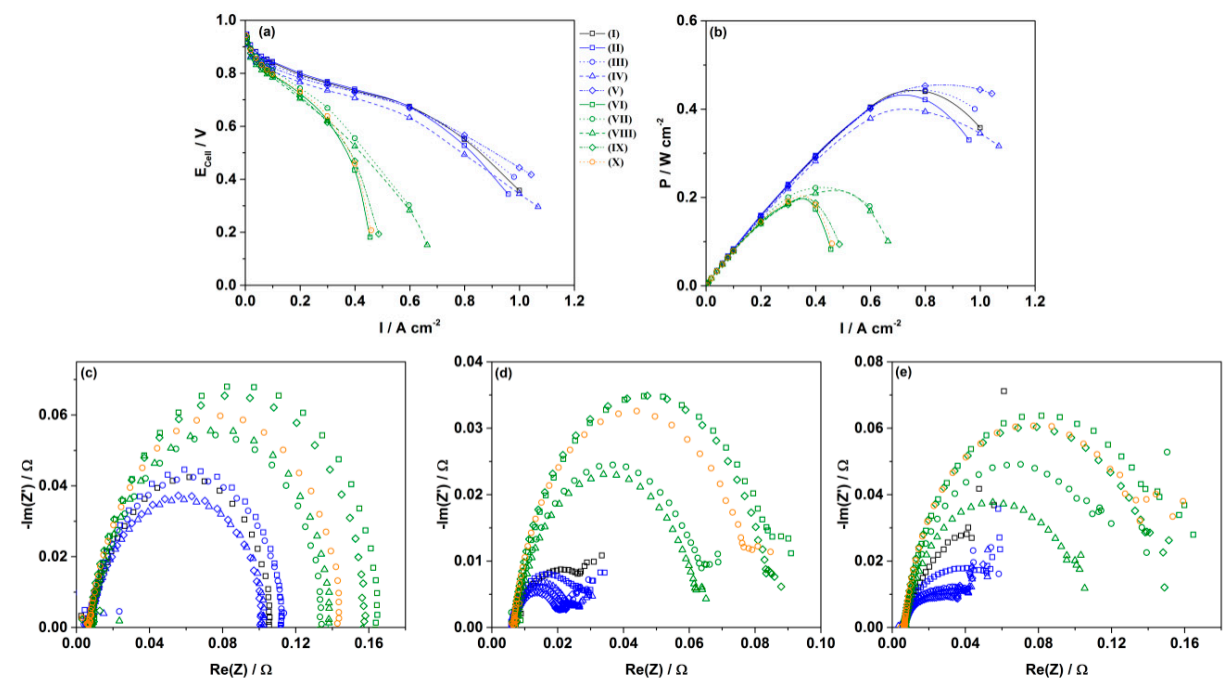

Figure 5. (a) Polarisation curves; (b) Power density curves and (c-e) EIS conducted at $0.48 \mathrm{~A}, 0.65 \mathrm{~V}$, and $0.5 \mathrm{~V}$ respectively on electrodes of (I) Pt/C (TKK); (II) Pt NWs /C (III) Pt NWs $/ \mathrm{C}\left(150{ }^{\circ} \mathrm{C}\right)$; (IV) Pt NWs $/ \mathrm{C}\left(250^{\circ} \mathrm{C}\right)$; (V) PtNWs $/ \mathrm{C}\left(350^{\circ} \mathrm{C}\right)$; (VI) PtNi NWs $/ \mathrm{C}$; (VII) PtNI NWs $/ \mathrm{C}\left(150^{\circ} \mathrm{C}\right)$; (VIII) PtNi NWs $/ \mathrm{C}\left(250^{\circ} \mathrm{C}\right)$; (IX) PtNi NWs $/ \mathrm{C}\left(350^{\circ} \mathrm{C}\right)$; and $(\mathrm{X}) \mathrm{PtNi} N W s / \mathrm{C}\left(150^{\circ} \mathrm{C}, 72 \mathrm{~h}\right)$.

A more stark difference in performance is however observed when comparing those samples containing Ni with the analogous samples of pure Pt. With Ni impregnation much lower power outputs are obtained in comparison to the Pt NWs/C samples. EIS (Figure $5 \mathrm{c}-\mathrm{e}$ ) confirms that both charge transfer and mass transport resistances for the PtNi NWs/C samples are higher in comparison to the $\mathrm{Pt}$ NWs/C samples despite improved catalytic activities observed in liquid half-cell measurement and the higher resistance to coarsening effects in annealing process. While in the TFRDE measurement the ECSA and mass activity can be used to ascertain the Pt surface to bulk ratio and surface activity, in a fuel cell device the catalytic activity more specifically represents the number of surface sites with access to protons to form triple phase boundary (TPB) in electrodes [6,43]. This depends on the morphology and catalytic activities of the catalyst, the distribution of Nafion ${ }^{\circledR}$ ionomer and also on the surface properties of the nanowires. PtNi catalyst surface usually shows a different hydrophilic feature as compared with the hydrophobic surface of pure Pt catalyst [44], and this can potentially lead to a much different contact with Nafion ${ }^{\circledR}$ ionomer in the catalyst layer and the distribution of produced water in fuel cell operation, thus altering the TPB and power performance. Furthermore, cation contaminants are known to exchange with the sulfonic groups of Nafion ${ }^{\circledR}$, altering not just the ionic conductivity, but also the oxygen diffusion coefficient in the ionomer which can exacerbate mass transport limitations in the catalyst layer [45].

It cannot be ruled that that some of the disparity between the activities with the TFRDE and the MEAs could also be due to different stabilities of the Ni from dissolution in each environment, where thicker Pt surface layers are required to protect the sub surface Ni in an MEA environment [6]. While the structural changes of the wires after leaching in each environment and the introduction of a de-alloying step is the focus of an ongoing study, this report serves to provide insights to the annealing behaviour of nanosized 1D Pt and PtNi catalysts at various temperatures and the immediate consequences on catalyst and single cell performance, with the addition of highlighting the challenges facing the adoption of similar novel catalyst materials in PEMFC electrodes.

\section{Conclusions}

A method of fabricating PtNi nanowires in a manner that can be adopted for any pre-existing Pt structure has been demonstrated in this work through an impregnation and subsequent annealing approach. The annealing behaviour of these nanosized 1D catalysts has been evaluated where it is 
shown that the Pt NWs/C sinters at an annealing temperature as low as $150{ }^{\circ} \mathrm{C}$. Therefore, while the surface cover of Ni onto the ultra-thin Pt NWs increases their thermal stability, only very low annealing temperatures can be employed on nanosized 1D Pt structures if the original morphology is to be retained. Physical characterisation in conjunction with liquid half-cell RDE measurements show that while higher annealing temperatures are required to increase the Pt lattice strain through an increase in Pt surface segregation in $\mathrm{Ni}$ impregnated samples, the retention of nanowire morphology for PtNi NWs $/ \mathrm{C}$ at $150{ }^{\circ} \mathrm{C}$ provides a 1.78 -fold mass activity improvement to the synthesised $\mathrm{Pt} \mathrm{NWs} / \mathrm{C}$ catalyst. The big differences in ECSA and mass activities detected in liquid half-cell measurement with the annealing temperature and duration results in very limited changes to the power performance of both Pt NWs/C and PtNi NWs/C electrodes in single PEMFC tests. Furthermore, worse performance is found for those samples with Ni resulting from the larger charge transfer and mass transport resistances. Indications are that the contact between the catalysts and electrolyte ionomer, and the surface Ni hydroxide species play a significant role in this poor performance although the precise mechanisms need to be investigated further. Acid leaching/dealloying is proposed to help alleviate the negative impact of surface $\mathrm{Ni}$ hydroxide species and will be crucial in realising the potential of novel PtNi catalyst structures to produce real high performance PEMFC devices.

Supplementary Materials: The following are available online at http://www.mdpi.com/1996-1944/11/8/1473/s1, Figure S1: STEM mode image and EDX element map of PtNi NWs $/ \mathrm{C}$ annealed at $350{ }^{\circ} \mathrm{C}$. The EDX map is of Pt (green) and $\mathrm{Ni}$ (red), Figure S2: TEM of PtNi NWs $/ \mathrm{C}\left(150^{\circ} \mathrm{C}, 72 \mathrm{~h}\right)$, Figure S3: XPS patterns of the Pt $4 \mathrm{f}$ regions of (a) PtNi NWs/C, (b) PtNi NWs $/ \mathrm{C}\left(150^{\circ} \mathrm{C}\right)$, (c) PtNi NWs/C $\left(250^{\circ} \mathrm{C}\right)$, (d) PtNi NWs $/ \mathrm{C}\left(350^{\circ} \mathrm{C}\right)$, (e) PtNi NWs $/ \mathrm{C}$ $\left(150{ }^{\circ} \mathrm{C}, 72 \mathrm{~h}\right)$ and $(\mathrm{f})$ the $\mathrm{Ni} 3 \mathrm{p}$ region of PtNi NWs $/ \mathrm{C}\left(150^{\circ} \mathrm{C}, 72 \mathrm{~h}\right)$, Figure S4: FFT 5 point smoothed TGA of (I) Pt NWs/C, (II) PtNi NWs/C, (III) PtNi NWs/C (150 $\left.{ }^{\circ} \mathrm{C}\right)$, (IV) PtNi NWs $/ C\left(250{ }^{\circ} \mathrm{C}\right)$ and (V) PtNi NWs $/ \mathrm{C}$ $\left(350{ }^{\circ} \mathrm{C}\right)$, Figure S5: (a) CVs of $25 \mu \mathrm{g}$ catalyst on a $0.196 \mathrm{~cm}^{2} \mathrm{GCE}$ in $\mathrm{N}^{2}$ saturated $0.1 \mathrm{M} \mathrm{HClO}_{4(\mathrm{aq})}$ electrolyte in the potential range $0.05-1.2 \mathrm{~V}$. (b) LSVs at $1600 \mathrm{rpm}$ in $\mathrm{O}^{2}$ saturated electrolyte from $0.05-1.2 \mathrm{~V}$ vs. RHE with a sweep rate of $20 \mathrm{mV} \mathrm{s}-1$. (c) Koutecky-Levich plots. The cell temperature was kept at $25^{\circ} \mathrm{C}$, Table S1: Average position and atm \% of the samples from 3 high resolution $\mathrm{Pt} 4 \mathrm{f}$ XPS spots, Table S2: Average position and atm \% of the samples from 3 high resolution Ni 3p XPS spots, Table S3: Ex-situ RDE measurement quantitative data.

Author Contributions: S.D. and P.M. conceived and designed the experiments; P.M. performed the experiments; P.M. analyzed the data; S.D. and P.M. wrote the paper.

Funding: This work is funded by the EPSRC Centre for Doctoral Training in Fuel Cells and their Fuels (EP/L015749/1).

Acknowledgments: The authors would like to thank Michael Fay and Rhys Lodge at the Nanoscale and Microscale Research Centre (NMRC) at the University of Nottingham for the TEM acquisition. X-ray photoelectron spectra were obtained at the National EPSRC X-ray XPS User's Service (NEXUS) at Newcastle University.

Conflicts of Interest: The authors declare no conflict of interest. The founding sponsors had no role in the design of the study; in the collection, analyses, or interpretation of data; in the writing of the manuscript, and in the decision to publish the results.

\section{References}

1. Nie, Y.; Li, L.; Wei, Z. Recent advancements in Pt and Pt-free catalysts for oxygen reduction reaction. Chem. Soc. Rev. 2015, 44, 2168-2201. [CrossRef] [PubMed]

2. Chen, C.; Kang, Y.; Huo, Z.; Zhu, Z.; Huang, W.; Xin, H.L.; Snyder, J.D.; Li, D.; Herron, J.A.; Mavrikakis, M.; et al. Highly Crystalline Multimetallic Nanoframes with Three-Dimensional Electrocatalytic Surfaces. Science 2014, 343, 1339-1343. [CrossRef] [PubMed]

3. Bu, L.; Ding, J.; Guo, S.; Zhang, X.; Su, D.; Zhu, X.; Yao, J.; Guo, J.; Lu, G.; Huang, X. A General Method for Multimetallic Platinum Alloy Nanowires as Highly Active and Stable Oxygen Reduction Catalysts. Adv. Mater. 2015, 27, 7204-7212. [CrossRef] [PubMed]

4. Bu, L.; Zhang, X.; Shen, X.; Su, D.; Lu, G.; Zhu, X.; Yao, J.; Guo, J.; Guo, S.; Huang, X. Surface engineering of hierarchical platinum-cobalt nanowires for efficient electrocatalysis. Nat. Commun. 2016, 7, 11850. [CrossRef] [PubMed]

5. Han, B.; Carlton, C.E.; Kongkanand, A.; Kukreja, R.S.; Theobald, B.R.; Gan, L.; O'Malley, R.; Strasser, P.; Wagner, F.T.; Shao-Horn, Y. Record activity and stability of dealloyed bimetallic catalysts for proton exchange membrane fuel cells. Energy Environ. Sci. 2015, 8, 258-266. [CrossRef] 
6. Kongkanand, A.; Mathias, M.F. The Priority and Challenge of High-Power Performance of Low-Platinum Proton-Exchange Membrane Fuel Cells. J. Phys. Chem. Lett. 2016, 7, 1127-1137. [CrossRef] [PubMed]

7. Alia, S.M.; Larsen, B.A.; Pylypenko, S.; Cullen, D.A.; Diercks, D.R.; Neyerlin, K.C.; Kocha, S.S.; Pivovar, B.S. Platinum-coated nickel nanowires as oxygen-reducing electrocatalysts. ACS Catal. 2014, 4, 1114-1119. [CrossRef]

8. Chen, T.W.; Kang, J.X.; Zhang, D.F.; Guo, L. Ultralong PtNi alloy nanowires enabled by the coordination effect with superior ORR durability. RSC Adv. 2016, 6, 71501-71506. [CrossRef]

9. Jiang, K.; Zhao, D.; Guo, S.; Zhang, X.; Zhu, X.; Guo, J.; Lu, G.; Huang, X. Efficient oxygen reduction catalysis by subnanometer Pt alloy nanowires. Sci. Adv. 2017, 3, e1601705. [CrossRef] [PubMed]

10. Stamenkovic, V.; Mun, B.S.; Mayrhofer, K.J.J.; Ross, P.N.; Markovic, N.M.; Rossmeisl, J.; Greeley, J.; Nørskov, J.K. Changing the Activity of Electrocatalysts for Oxygen Reduction by Tuning the Surface Electronic Structure. Angew. Chem. 2006, 118, 2963-2967. [CrossRef]

11. Wang, X.; Orikasa, Y.; Takesue, Y.; Inoue, H.; Nakamura, M.; Minato, T.; Hoshi, N.; Uchimoto, Y. Quantitating the lattice strain dependence of monolayer Pt shell activity toward oxygen reduction. J. Am. Chem. Soc. 2013, 135, 5938-5941. [CrossRef] [PubMed]

12. Sun, S.; Zhang, G.; Geng, D.; Chen, Y.; Li, R.; Cai, M.; Sun, X. A highly durable platinum nanocatalyst for proton exchange membrane fuel cells: Multiarmed starlike nanowire single crystal. Angew. Chem. Int. Ed. 2011, 50, 422-426. [CrossRef] [PubMed]

13. Lu, Y.; Du, S.; Steinberger-Wilckens, R. One-dimensional nanostructured electrocatalysts for polymer electrolyte membrane fuel cells-A review. Appl. Catal. B Environ. 2016, 199, 292-314. [CrossRef]

14. Elvington, M.C.; Colón-Mercado, H.R. Pt and Pt/Ni “Needle” Eletrocatalysts on Carbon Nanotubes with High Activity for the ORR, Electrochem. Solid State Lett. 2012, 15, K19-K22. [CrossRef]

15. Alia, S.M.; Pylypenko, S.; Dameron, A.; Neyerlin, K.C.; Kocha, S.S.; Pivovar, B.S. Oxidation of Platinum Nickel Nanowires to Improve Durability of Oxygen-Reducing Electrocatalysts. J. Electrochem. Soc. 2016, 163, F296-F301. [CrossRef]

16. Alia, S.M.; Ngo, C.; Shulda, S.; Ha, M.A.; Dameron, A.A.; Weker, J.N.; Neyerlin, K.C.; Kocha, S.S.; Pylypenko, S.; Pivovar, B.S. Exceptional Oxygen Reduction Reaction Activity and Durability of Platinum-Nickel Nanowires through Synthesis and Post-Treatment Optimization. ACS Omega 2017, 2, 1408-1418. [CrossRef]

17. Pivovar, B. 2017 DOE Hydrogen and Fuel Cells Program Review: Extended Surface Electrocatalyst Development; US Department of Energy: Washington, DC, USA, 2017.

18. Du, S.; Lin, K.; Malladi, S.K.; Lu, Y.; Sun, S.; Xu, Q.; Steinberger-Wilckens, R.; Dong, H. Plasma nitriding induced growth of Pt-nanowire arrays as high performance electrocatalysts for fuel cells. Sci. Rep. 2014, 4, 6439-6444. [CrossRef] [PubMed]

19. Lu, Y.; Du, S.; Steinberger-Wilckens, R. Temperature-controlled growth of single-crystal Pt nanowire arrays for high performance catalyst electrodes in polymer electrolyte fuel cells. Appl. Catal. B Environ. 2015, 164, 389-395. [CrossRef]

20. Lu, Y.; Du, S.; Steinberger-Wilckens, R. Three-dimensional catalyst electrodes based on PtPd nanodendrites for oxygen reduction reaction in PEFC applications. Appl. Catal. B Environ. 2016, 187, 108-114. [CrossRef]

21. Sun, S.; Jaouen, F.; Dodelet, J.P. Controlled growth of Pt nanowires on carbon nanospheres and their enhanced performance as electrocatalysts in PEM fuel cells. Adv. Mater. 2008, 20, 3900-3904. [CrossRef]

22. Garsany, Y.; Baturina, O.A.; Swider-Lyons, K.E.; Kocha, S.S. Experimental Methods for Quantifying the Activity of Platinum Electrocatalysts for the Oxygen Reduction Reaction. Anal. Chem. 2010, 82, 6321-6328. [CrossRef] [PubMed]

23. Schmidt, T.J.; Gasteiger, H.A.; Stäb, G.D.; Urban, P.M.; Kolb, D.M.; Behm, R.J. Characterization of High-Surface-Area Electrocatalysts Using a Rotating Disk Electrode Configuration. J. Electrochem. Soc. 1998, 145, 2354-2358. [CrossRef]

24. Łukaszewski, M.; Soszko, M.; Czerwiński, A. Electrochemical Methods of Real Surface Area Determination of Noble Metal Electrodes-An Overview. Int. J. Electrochem. Sci. 2016, 11, 4442-4469. [CrossRef]

25. Tsotridis, G.; Pilenga, A.; de Marco, G.; Malkow, T. EU Harmonised Test Protocols for PEMFC MEA Testing in Single Cell Configuration for Automotive Applications. JRC Sci. Policy Rep. 2015. [CrossRef] 
26. Du, S.; Lu, Y.; Steinberger-Wilckens, R. PtPd nanowire arrays supported on reduced graphene oxide as advanced electrocatalysts for methanol oxidation. Carbon 2014, 79, 346-355. [CrossRef]

27. Chen, J.; Herricks, T.; Geissler, M.; Xia, Y. Single-Crystal Nanowires of Platinum can be Synthesized by Controlling the Reaction Rate of a Polyol Process. J. Am. Chem. Soc. 2004, 126, 10854-10855. [CrossRef] [PubMed]

28. Meng, H.; Zhan, Y.; Zeng, D.; Zhang, X.; Zhang, G.; Jaouen, F. Factors Influencing the Growth of Pt Nanowires via Chemical Self-Assembly and their Fuel Cell Performance. Small 2015, 11, 3377-3386. [CrossRef] [PubMed]

29. Shrestha, S.; Liu, Y.; Mustain, W.E. Electrocatalytic Activity and Stability of Pt clusters on State-of-the-Art Supports: A Review Electrocatalytic Activity and Stability of Pt clusters on State-of-the-Art Supports. Catal. Rev. Sci. Eng. 2011, 53, 256-336. [CrossRef]

30. Mukerjee, S.; Srinivasan, S.; Soriaga, M.P.; McBreen, J. Effect of Preparation Conditions of Pt Alloys on Their Electronic, Structural, and Electrocatalytic Activities for Oxygen Reduction-XRD, XAS and Electrochemical Studies. J. Phys. Chem. 1995, 99, 4577-4589. [CrossRef]

31. Zignani, S.; Baglio, V.; Sebastián, D.; Saccà, A.; Gatto, I.; Aricò, A. Towards Highly Performing and Stable PtNi Catalysts in Polymer Electrolyte Fuel Cells for Automotive Application. Materials 2017, 10, 317. [CrossRef] [PubMed]

32. Antolini, E.; Salgado, J.R.C.; dos Santos, A.M.; Gonzalez, E.R. Carbon-Supported Pt-Ni Alloys Prepared by the Borohydride Method as Electrocatalysts for DMFCs. Electrochem. Solid State Lett. 2005, 8, A226-A230. [CrossRef]

33. Wang, C.; Chi, M.; Li, D.; Strmcnik, D.; van der Vliet, D.; Wang, G.; Komanicky, V.; Chang, K.C.; Paulikas, A.P.; Tripkovic, D.; et al. Design and synthesis of bimetallic electrocatalyst with multilayered Pt-skin surfaces. J. Am. Chem. Soc. 2011, 133, 14396-14403. [CrossRef] [PubMed]

34. Ma, Y.; Balbuena, P.B. Pt surface segregation in bimetallic Pt3M alloys: A density functional theory study. Surf. Sci. 2008, 602, 107-113. [CrossRef]

35. Sato, T.; Nakamura, T.; Ozawa, F. Thermal Decomposition of Nickel Hydroxide. J. Appl. Chem. Biotechnol. 1975, 25, 583-590. [CrossRef]

36. Shao, M.; Chang, Q.; Dodelet, J.P.; Chenitz, R. Recent Advances in Electrocatalysts for Oxygen Reduction Reaction. Chem. Rev. 2016, 116, 3594-3657. [CrossRef] [PubMed]

37. Gasteiger, H.A.; Kocha, S.S.; Sompalli, B.; Wagner, F.T. Activity benchmarks and requirements for Pt, Pt-alloy, and non-Pt oxygen reduction catalysts for PEMFCs. Appl. Catal. B Environ. 2005, 56, 9-35. [CrossRef]

38. Du, S.; Koenigsmann, C.; Sun, S. One-Dimensional Nanostructures for PEM Fuel Cell Applications; Elsevier: Cambridge, MA, USA, 2017.

39. Moniri, S.; van Cleve, T.; Linic, S. Pitfalls and best practices in measurements of the electrochemical surface area of platinum-based nanostructured electro-catalysts. J. Catal. 2017, 345, 1-10. [CrossRef]

40. Kinoshita, K. Particle Size Effects for Oxygen Reduction on Highly Dispersed Platinum in Acid Electrolytes. J. Electrochem. Soc. 1990, 137, 845-848. [CrossRef]

41. Du, S. A Facile Route for Polymer Electrolyte Membrane Fuel Cell Electrodes with in situ Grown Pt Nanowires. J. Power Sources 2010, 195, 289-292. [CrossRef]

42. Du, S.; Millington, B.; Pollet, B.G. The effect of Nafion ionomer loading coated on gas diffusion electrodes with in-situ grown Pt nanowires and their durability in proton exchange membrane fuel cells. Int. J. Hydrogen Energy 2011, 36, 4386-4393. [CrossRef]

43. Ifan, B.; Lester, E.; Rossmeisl, J.; Chorkendorff, I. Toward sustainable fuel cells. Science 2016, 354, 1378-1380.

44. Debe, M.K. Electrocatalyst approaches and challenges for automotive fuel cells. Nature 2012, 486, 43-51. [CrossRef] [PubMed]

45. Antolini, E.; Salgado, J.R.C.; Gonzalez, E.R. The stability of Pt-M (M = first row transition metal) alloy catalysts and its effect on the activity in low temperature fuel cells. A literature review and tests on a Pt-Co catalyst. J. Power Sources 2006, 160, 957-968. [CrossRef]

(C) 2018 by the authors. Licensee MDPI, Basel, Switzerland. This article is an open access article distributed under the terms and conditions of the Creative Commons Attribution (CC BY) license (http:/ / creativecommons.org/licenses/by/4.0/). 